\title{
Comparison of biomass and nutrient content between oak (Quercus petraea) and hornbeam (Carpinus betulus) trees in a coppice-with-standards stand in Chimay (Belgium)
}

\author{
Frédéric ANDRÉ*, Quentin PONETTE \\ Université Catholique de Louvain, Unité des eaux et forêts, Croix du Sud, 2 bte 9, 1348 Louvain-la-Neuve, Belgique
}

(Received 22 October 2002; accepted 17 February 2003)

\begin{abstract}
The management of forest stands on acid soils requires information on nutrient exports under various harvesting scenarios. Twenty one oaks (Quercus petraea (Mattuschka) Liebl.) and eighteen hornbeams (Carpinus betulus L.) were destructively sampled from a coppicewith-standards stand located on a dystrochrept soil in the Belgian Atlantic Fagne. Regression equations were developed (i) to quantify the partitioning of aboveground biomass and nutrient (N, P, K, Ca, Mg, S) content between the two component species at the stand level, (ii) to estimate the biomass and nutrient content distribution (stemwood, stembark, branchwood/branchbark from various diameter classes) within the two species as a function of breast height diameter, and (iii) to assess the pattern of nutrient concentrations within and between oak stems. For branches (dead and alive) and stems, weighted mean concentrations (wood + bark) tended to be higher in hornbeams for all elements except Ca in stems and $\mathrm{K}$ in all components. For both species, nutrient concentrations in live branches decreased with increasing branch diameter $(0-1 \mathrm{~cm}$ up to $>21 \mathrm{~cm}$ ), except for $\mathrm{Ca}$ in oaks. For oaks stems and large branches, a steep increase in Ca concentrations was noted in bark tissues compared to wood. At the stand level, $81 \%$ of total biomass and from $67 \%(\mathrm{Mg})$ to $87 \%(\mathrm{Ca})$ of total nutrient contents were associated with oak trees. Aboveground nutrient contents represented from $30 \%(\mathrm{Mg})$ to $270 \%(\mathrm{Ca})$ of the $0-40 \mathrm{~cm}$ exchangeable soil pools. Assuming the felling of all oak trees, the harvest of crowns and stems was shown to increase nutrient exports from $85 \%(\mathrm{Ca})$ to $281 \%$ ( $\mathrm{Mg}$ ) in comparison with a stem only scenario.
\end{abstract}

biomass / nutrient content / oak / hornbeam / coppice-with-standards

Résumé - Comparaison de la biomasse et de la minéralomasse du chêne (Quercus petraea) et du charme (Carpinus betulus) dans un taillis-sous-futaie à Chimay (Belgique). L'estimation de l'exportation des éléments nutritifs selon différents scénarios sylvicoles est indispensable pour la gestion durable des forêts sur sols acides. Vingt et un chênes (Quercus petraea (Mattuschka) Liebl.) et dix-huit charmes (Carpinus betulus L.) ont été sélectionnés au sein d'un taillis-sous-futaie croissant sur sol brun acide dans la Fagne Atlantique belge. Les équations de régression obtenues permettent (i) de quantifier la répartition de la biomasse et des minéralomasses $(\mathrm{N}, \mathrm{P}, \mathrm{K}, \mathrm{Ca}, \mathrm{Mg}, \mathrm{S})$ aériennes entre les deux espèces à l'échelle du peuplement, (ii) d'estimer, au sein des deux espèces, la distribution de la biomasse et des minéralomasses (bois du tronc, écorce du tronc, bois des branches / écorce des branches pour différentes catégories de diamètre) en fonction du diamètre du tronc et (iii) d'évaluer, chez le chêne, le profil moyen de concentration des nutriments dans le tronc ainsi que la variabilité inter-arbres des concentrations du tronc. Le charme présente des concentrations moyennes généralement plus élevées que le chêne, excepté pour le Ca dans les troncs et pour le $\mathrm{K}$ dans tous les organes (troncs et branches mortes ou vivantes). Pour les deux espèces, les concentrations dans les branches vivantes diminuent lorsque le diamètre des branches augmente (de $0-1 \mathrm{~cm}$ à $>21 \mathrm{~cm}$ ), sauf pour le $\mathrm{Ca}$ chez le chêne. Au niveau des troncs et des grosses branches de chêne, les concentrations en Ca de l'écorce sont nettement supérieures à celles du bois. À l'échelle du peuplement, $81 \%$ de la biomasse totale et $67 \%(\mathrm{Mg})$ à $87 \%(\mathrm{Ca})$ des minéralomasses totales sont associés aux chênes. Les minéralomasses aériennes représentent $30 \%(\mathrm{Mg})$ à $270 \%(\mathrm{Ca})$ du stock d'éléments échangeables du sol entre 0 et $40 \mathrm{~cm}$. Par rapport à une exploitation limitée aux troncs, la collecte supplémentaire des houppiers de tous les chênes accroît les exportations de $85 \%$ (Ca) à $281 \%(\mathrm{Mg})$.

biomasse / minéralomasse / chêne / charme / taillis-sous-futaie

\section{INTRODUCTION}

Whatever the main objective assigned to forests, forest management has to maintain long term ecosystem stability and productivity. This requires to act so as to maintain site fertility; the latter often closely depends on the dynamics of those nutrients that are essential in tree physiological processes $[12,14]$.
Biological cycle refers to the continuous circulation of nutrients between rooted soil horizons, trees and organic layers at the soil surface [24]. Part of the nutrients absorbed from the soil by tree roots return to the soil either via litterfall, release from dead roots or root exsudations or by way of throughfall and stemflow. The other part is immobilised more definitely in trunks, large branches and roots. Biological cycle

* Corresponding author: frederic.andre@efor.ucl.ac.be 
also presents external connections with inputs from the atmosphere (e.g. nitrogen biological fixation, deposition from rain and aerosols) and nutrient release from soil weathering. In managed stands, the main outputs from the system consist of run-off or drainage below the rooting zone and exports resulting from biomass harvesting. Due to the generally limited inherent soil fertility and low amounts of controlled anthropogenic inputs under forest stands [22], careful monitoring of nutrient exports in harvesting operations is of upmost importance. In addition to bulk nutrient content assessment at the stand level, detailed distribution of nutrients between and within tree components is needed to make realistic predictions of nutrient exports under various harvesting scenarios, as well as to gain insight in tree nutrient strategy. For a given species, site and stand age, the variability of nutrient concentrations among trees is associated to an array of factors such as crown class [7] and access to soil resources; these are partly reflected by the relative tree size. Within trees, concentrations also vary between the different components and tissues. Finally, the effects of all these factors are nutrient dependent [2, 27].

Up to now, incomplete information is available about nutrient accumulation in mixed stands, especially in coppice-withstandards, a widespread silvicultural regime in Belgium and France [16, 21]. Moreover, the partitioning of nutrient contents among branches of varying sizes remains largely unknown. Such data are important since crown components should represent an increasing portion of harvested biomass, for use as fuelwood and serve as an alternative, renewable energy source [15].

The main objectives of this paper are the following: (i) to quantify the partitioning of biomass and nutrient contents of a coppice-with-standards stand between the two component tree species, namely oaks (Quercus petraea (Mattuschka) Liebl.) and hornbeams (Carpinus betulus L.); (ii) to obtain detailed information on the biomass and nutrient content distribution within the two species, giving a special emphasis to the crown components. In addition, the pattern of nutrient concentrations within and between tree stems is assessed for the oaks.

\section{MATERIALS AND METHODS}

\subsection{Study site}

This research was carried out in an oak and hornbeam coppicewith-standards stand under conversion located in the "Bois SaintGeorges" (50 06' 46" N, 4 ${ }^{\circ} 17^{\prime} 05^{\prime \prime}$ E), near Chimay (Belgium), at an elevation of about $250 \mathrm{~m}$ above sea level. The choice of the site was strongly motivated by the presence, within the same stand, of a level II plot of the European Intensive Monitoring Network of Forest Ecosystems (ICP-Forest).

The primary geological strata are composed of Famennian shales (upper Devonian) which weather to heavy clay. The soil has a structural B horizon, and is classified as "Dystrochrept" (USDA soil taxonomy) or "sol brun acide" [28]. The limited drainage induces moderate gleyfication between 40 and $80 \mathrm{~cm}$ depth, just above a weathering clay layer that forms an abrupt transition with the hard schist [26].

Some relevant chemical properties of the upper (holorganic horizon and $0-40 \mathrm{~cm}$ layer) soil are shown in Table $\mathrm{I} . \mathrm{pH}_{\mathrm{H}_{2} \mathrm{O}}$ is $\leq 4.5$. The concentrations of all exchangeable base cations $(\mathrm{Ca}, \mathrm{Mg}, \mathrm{K})$ are consistently low and their sum accounts to no more than $14 \%$ of Effective Cation Exchange Capacity (ECEC). Total (aqua regia) concentrations in the 0-40 cm soil layer are much higher for $\mathrm{K}$ and $\mathrm{Mg}$, compared to $\mathrm{Ca}$; by contrast, Ca dominates in the LFH horizon, showing a strong accumulation relative to the mineral layers.

Mean annual precipitation ranges from $800 \mathrm{~mm}$ to $1130 \mathrm{~mm}$ with 320 to $470 \mathrm{~mm}$ between May and September. Mean annual temperature is $8.5^{\circ} \mathrm{C}$ with January and July means of $1.5^{\circ} \mathrm{C}$ and $16^{\circ} \mathrm{C}$, respectively. The prevailing wind direction is south to southwest.

Stand characteristics of the ICP-Forest level II plot are given in Table II. With $16.8 \mathrm{~m}^{2} \mathrm{ha}^{-1}$, oak trees (Quercus petraea Liebl.) makes up about two thirds of total stand basal area $\left(24.8 \mathrm{~m}^{2} \mathrm{ha}^{-1}\right)$. The structure of the standards looks that of an even-aged stand as a result of progressive conversion.

\subsection{Measurements and sampling}

\subsubsection{Trees}

Twenty-one oaks and eighteen hornbeams were selected amongst the standards and the coppice stems, respectively. Their choice was

Table I. Selected soil chemical properties of the ICP-Forest level II plot of Chimay.

\begin{tabular}{|c|c|c|c|c|c|c|c|c|c|c|c|c|}
\hline \multirow[t]{2}{*}{ Layer } & \multirow[t]{2}{*}{$\mathrm{pH}_{\mathrm{H}_{2} \mathrm{O}}$} & \multirow[t]{2}{*}{$\mathrm{C}^{(1)}$} & \multirow[t]{2}{*}{$\mathrm{N}^{(2)}$} & \multirow[t]{2}{*}{$\mathrm{C} / \mathrm{N}$} & \multicolumn{4}{|c|}{ Exchangeable cations $^{(3)}$} & \multicolumn{4}{|c|}{ Extractable pools $^{(4)}$} \\
\hline & & & & & K & $\mathrm{Mg}$ & $\mathrm{Ca}$ & $\operatorname{ECEC}^{(5)}$ & K & $\mathrm{Mg}$ & $\mathrm{Ca}$ & $\mathrm{P}$ \\
\hline & \multicolumn{4}{|c|}{$(\mathrm{mg} / \mathrm{kg})$} & \multicolumn{4}{|c|}{$(\mathrm{cmolc} / \mathrm{kg})$} & \multicolumn{3}{|c|}{ (cmolc/kg) } & $(\mathrm{mg} / \mathrm{kg})$ \\
\hline LFH & 4.5 & 380 & 21.5 & 18 & & & & & 6.71 & 13.00 & 25.70 & 1416 \\
\hline $0-10 \mathrm{~cm}$ & 4.1 & 58 & 3.2 & 18 & $\begin{array}{l}0.29 \\
(3.3)\end{array}$ & $\begin{array}{l}0.28 \\
(3.2)\end{array}$ & $\begin{array}{l}0.64 \\
(7.3)\end{array}$ & 8.78 & 13.69 & 31.58 & 0.98 & 784 \\
\hline $10-20 \mathrm{~cm}$ & 4.2 & 26 & 1.4 & 19 & $\begin{array}{l}0.16 \\
(2.5)\end{array}$ & $\begin{array}{l}0.14 \\
(2.2)\end{array}$ & $\begin{array}{l}0.20 \\
(3.1)\end{array}$ & 6.42 & 16.26 & 36.20 & 0.62 & 696 \\
\hline \multirow[t]{2}{*}{$20-40 \mathrm{~cm}$} & 4.3 & 19 & 1.0 & 19 & $\begin{array}{l}0.14 \\
(2.2)\end{array}$ & $\begin{array}{l}0.24 \\
(3.8)\end{array}$ & $\begin{array}{l}0.20 \\
(3.1)\end{array}$ & 6.36 & 18.10 & 39.08 & 0.40 & 628 \\
\hline & & & & \multicolumn{9}{|c|}{ Pools (kg/ha) } \\
\hline $\mathrm{LFH}$ & & & & & & & & & 63 & 38 & 124 & 34 \\
\hline $0-40 \mathrm{~cm}$ & & & & & 297 & 114 & 255 & & 27761 & 19026 & 499 & 2900 \\
\hline $\begin{array}{l}\text { (1) Organic } \\
\text { (2) N Kjeld } \\
\text { (3) Extracte } \\
\text { (4) Aqua re } \\
\text { (5) ECEC: }\end{array}$ & $\begin{array}{l}\text { erminec } \\
0.1 \mathrm{M} \\
\text { gestion. } \\
\text { ive Cati }\end{array}$ & $\begin{array}{l}\text { dry } \\
\mathrm{Cl}_{2} . \mathrm{I} \\
\text { Exch }\end{array}$ & $\begin{array}{l}\text { busti } \\
\text { bers } \\
\text { Cap }\end{array}$ & def & me & $\mathrm{n}$ of $\mathrm{e}$ & geable & ons and e & ons rela & $\begin{array}{l}\text { to ECEC. } \\
\text { idity }\left(\mathrm{H}^{+}\right.\end{array}$ & $\mathrm{Al}^{3}$ & ons \\
\hline
\end{tabular}


Table II. ICP-Forest level II plot stand characteristics ${ }^{(1)}$ (total inventory, 2000).

\begin{tabular}{lccccc}
\hline Species & $\mathrm{N} / \mathrm{ha}$ & \multicolumn{2}{c}{$\mathrm{C} 130(\mathrm{~cm})$} & Basal area $\left(\mathrm{m}^{2} / \mathrm{ha}\right) \mathrm{V}^{(2)}\left(\mathrm{m}^{3} / \mathrm{ha}\right)$ \\
\multicolumn{5}{c}{ Mean } & Range \\
\hline Quercus petraea & 76 & 163.5 & {$[48-208]$} & 16.8 & 183 \\
Carpinus betulus & 978 & 30.2 & {$[10-77]$} & 8.0 & 32 \\
Total & 1054 & & & 24.8 & 215 \\
\hline
\end{tabular}

(1) Plot surface $=0.5$ ha.

(2) Commercial volume (Outside bark volume of stem and branch parts above $7 \mathrm{~cm}$ diameter)

Volume equation established from measurements on the sampled trees of this study.

carried out on the basis of the basal area distribution of each species in the stand. The general shape of the tree was a second selection criteria to avoid ill-formed individuals with strong forks or any other peculiarity. The trees were felled in 2000 , outside the growing season. Dendrometric measurements carried out on the sampled trees before and after felling are summarised in Table III together with their corresponding ranges.

Oak stem was defined as the main axis extending from the soil to the "Delevoy" height, i.e. height at which stem circumference is half the circumference at breast height. A comparison between various height measurements for sampled oak trees (total height: Ht, height of widest crown lateral development: Hc, height of the lowest living branch: Hlb, and Delevoy height: $\mathrm{Hd}$ ) showed a strong correlation between $\mathrm{Hd}$ and $\mathrm{Hc}$, Hc being on average a bit lower than $\mathrm{Hd}$. Whereas Ht increased regularly with tree girth at $1.3 \mathrm{~m}$ (C130), Hd and Hc were both more or less constant; Hc, which approximates the level at which competition appears between neighbouring trees, is indeed expected to be constant in a coppice-with-standards stand such as this one. The proportion of $\mathrm{Hc}$ (or $\mathrm{Hd}$ ) to $\mathrm{Ht}$ varied between $60 \%$ and $70 \%$ for the tallest and the smallest trees, respectively. For hornbeams, the diameter of upper stem limit was arbitrarily fixed at $1 \mathrm{~cm}$; the corresponding height was about $90 \%$ of total tree height irrespective of tree size. For both species, parts of the trees above the previously defined heights together with the branches attached to the stem were considered as crown. The age of the sampled oaks was determined from a disk taken at the base of the trunk; it ranged from 37 to 182 years.

Stems were sliced into $0.5 \mathrm{~m}$ (oaks) or $1 \mathrm{~m}$ long (hornbeams) logs for the lower 0-2 meters bole, and into $2 \mathrm{~m}$ long ones above. For the living branches, six diameter classes $(<1 \mathrm{~cm}, 1-4 \mathrm{~cm}, 4-7 \mathrm{~cm}$,
$7-14 \mathrm{~cm}, 14-21 \mathrm{~cm}$ and $>21 \mathrm{~cm}$ ) were individualised. All dead branches were included in a single class, irrespective of their size. All these components were weighted fresh in the field immediately after sorting, by means of an electronic balance hanging on the front hoist of a tractor.

A $3 \mathrm{~cm}$-thick disk was taken from the lower section of each bole $\log$, and five or ten discs were randomly removed from each branch category. These discs were labelled, put into plastic bags and sent to the laboratory for the following determinations: (i) water content (constant weight at $65{ }^{\circ} \mathrm{C}$ ), (ii) weight proportion of woody tissues (see below), and (iii) nutrient concentrations. For the oak trees, woody tissues were further separated for the stem (heartwood, sapwood, bark) and for the $>7 \mathrm{~cm}$ diameter branches (wood, bark). Tissue separation was carried out from two triangular portions of constant open angles cut out from the disks, one in the direction of the shortest radius, and the other following the largest one.

The material from each disk was then pooled by tissue and branch size or stem level before grinding and chemical analyses.

\subsubsection{Soil}

Soil was sampled in the ICP-Forest level II plot of Chimay. In order to take into account spatial variability at the plot level, sampling was made at 5 locations within the plot, four near the corners and one at the centre. At each location, 5 individual sampling points were randomly selected from 16 equally spaced points defined by a $13.5 \mathrm{~m}$ side square grid. Four layers were separated: the holorganic horizons (LFH) and the mineral $0-10 \mathrm{~cm}, 10-20 \mathrm{~cm}$ and $20-40 \mathrm{~cm}$ soil layers. The samples were then pooled together by grid and layer, and ground to pass a $2 \mathrm{~mm}$ sieve prior to analysis. At each location, total ovendry weight per surface unit (holorganic layers) and dry bulk density of the $<2 \mathrm{~mm}$ soil fraction (mineral layers) were estimated from a composite of 5 individual samples.

\subsection{Chemical analyses}

\subsubsection{Wood and bark}

The samples were analysed for nitrogen $(\mathrm{N})$, calcium $(\mathrm{Ca})$, magnesium $(\mathrm{Mg})$, potassium $(\mathrm{K})$, phosphorus $(\mathrm{P})$ and sulphur $(\mathrm{S})$ content. Nitrogen was determined using Kjeldahl procedure. For the other elements, the samples were processed using dry ashing at $450{ }^{\circ} \mathrm{C}$ followed by solubilisation in $\mathrm{HCl}$. $\mathrm{Ca}, \mathrm{Mg}, \mathrm{K}, \mathrm{P}$ were measured by atomic emission spectroscopy (ICP), and $\mathrm{S}$ was determined colorimetrically [4]. For each combination of component and tissue, the

Table III. Dendrometric measurements performed on the sampled trees ${ }^{(1)}$

\begin{tabular}{|c|c|c|}
\hline \multirow{2}{*}{ Species } & \multicolumn{2}{|c|}{ Measurements } \\
\hline & Before felling & After felling \\
\hline Oaks & $\begin{array}{l}\text { - } \text { circumference at breast height }(\mathrm{C} 130)[48-208 \mathrm{~cm}] \\
\text { - total height }(\mathrm{Ht})[15.6-23.5 \mathrm{~m}] \\
\text { - } \text { crown height }^{(2)}(\mathrm{Hc})[8.3-14.5 \mathrm{~m}] \\
\text { - first living branch height }{ }^{(3)}(\mathrm{Hlb})[5.5-12.8 \mathrm{~m}] \\
\text { - } \text { crown radius }^{(4)}(\mathrm{Rc})[1.6-7.2 \mathrm{~m}]\end{array}$ & $\begin{array}{l}\text { - total height }(\mathrm{Ht})[16.1-23.1 \mathrm{~m}] \\
\text { - Delevoy height }(5)(\mathrm{Hd})[10.3-15.5 \mathrm{~m}] \\
\text { - stem diameter at different heights }\end{array}$ \\
\hline Hornbeams & $\begin{array}{l}\text { - circumference at breast height }(\mathrm{C} 130)[10-77 \mathrm{~cm}] \\
\text { - total height }(\mathrm{Ht})[4.5-22.9 \mathrm{~m}]\end{array}$ & $\begin{array}{l}\text { - total height }(\mathrm{Ht})[5.4-18.9 \mathrm{~m}] \\
\text { - height at stem diameter of } 1 \mathrm{~cm} \\
\text { - } \text { stem diameter at different heights }\end{array}$ \\
\hline
\end{tabular}

(1) Values between square brackets are the ranges for the sampled trees.

(2) Hc: Height, from the ground, of widest crown lateral development.

(3) Hlb: Height, from the ground, of the stem insertion point of the lowest living branch.

(4) Rc: Arithmetic mean of crown radius measured in height cardinal directions (N, NE, E, SE, S, SW, W, NW).

(5) Hd: Height, from the ground, at which stem circumference is half the circumference at breast height (Delevoy height). 
nutrient contents were computed as the product of mean nutrient concentration and corresponding dry weight.

\subsubsection{Soil}

Organic carbon and nitrogen were analysed using dry combustion and Kjeldahl procedures, respectively. Exchangeable cations were extracted with $0.1 \mathrm{M} \mathrm{BaCl}_{2}$, whereas the so called "total" pool was extracted with aqua regia reagent (wet destruction with a mixture of $\mathrm{HCl}, \mathrm{HNO}_{3}$ and $\mathrm{H}_{2} \mathrm{O}_{2}$ ). Atomic emission spectroscopy was used to determine $\mathrm{P}$ and cation concentrations in both extracts. Nutrient stores in the soil were calculated, using concentrations and either dry weights per surface unit (holorganic horizons) or dry bulk densities (mineral layers).

\subsection{Statistics}

Least squares regression technique was used to establish equations predicting biomass/nutrient contents of the various components, including total tree, from single or combined individual tree characteristics (circumference at breast height: C130, total height: $\mathrm{Ht}$, and mean crown radius: $\mathrm{Rcm}$ ), or some power of them. Several linear or linearizable (logarithmic) models were tested and the best prediction models were chosen based on statistic criteria (adjusted $\mathrm{R}^{2}$, squared residuals sum, weak collinearity between independent variables, and residuals homoscedasticity). When necessary, Baskerville's correction was applied to correct for the bias resulting from log transformation [29]. Similar procedures were used to assess the variability of nutrient concentrations between tree stems of the same species. All computations were performed using SAS Proc Reg procedure (SAS institute, version 8.02).

For the assessment of the variability of nutrient concentrations at the stem level, models and parameters estimates were obtained using SAS Proc Mixed algorithms, which enabled to take into account autocorrelation structures [18]. The models expressed concentrations of a given element (and stem tissue for the oak trees) as a function of sampling height, considering "tree" as a random factor. The selected covariance structure was "First-Order Autoregressive", which assumes decreasing correlation between concentrations as distance between their sampling locations increases.

All statistical tests were performed at a 0.05 significance level.

\section{RESULTS}

\subsection{Nutrient concentrations}

We consider successively the effects of (i) element, species, and component, (ii) tissue, (iii) tree size, (iv) sampling height, and (v) branch diameter, on nutrient concentrations.

\subsubsection{Element, species and component}

Figure 1 shows the weighted mean nutrient concentrations with their confidence intervals for the dead branches (DB), the living branches (LB) and the stems (S). For both species, two groups of elements can be separated on a concentration basis: $\mathrm{N}, \mathrm{K}, \mathrm{Ca} \gg \gg>\mathrm{P}, \mathrm{Mg}, \mathrm{S}$.

For each component, mean nutrient concentrations are generally higher in hornbeams than in oaks, except for potassium in all compartments and for calcium in stems. For $\mathrm{N}, \mathrm{Mg}$, and $\mathrm{S}$, the differences between species are significant for all com-

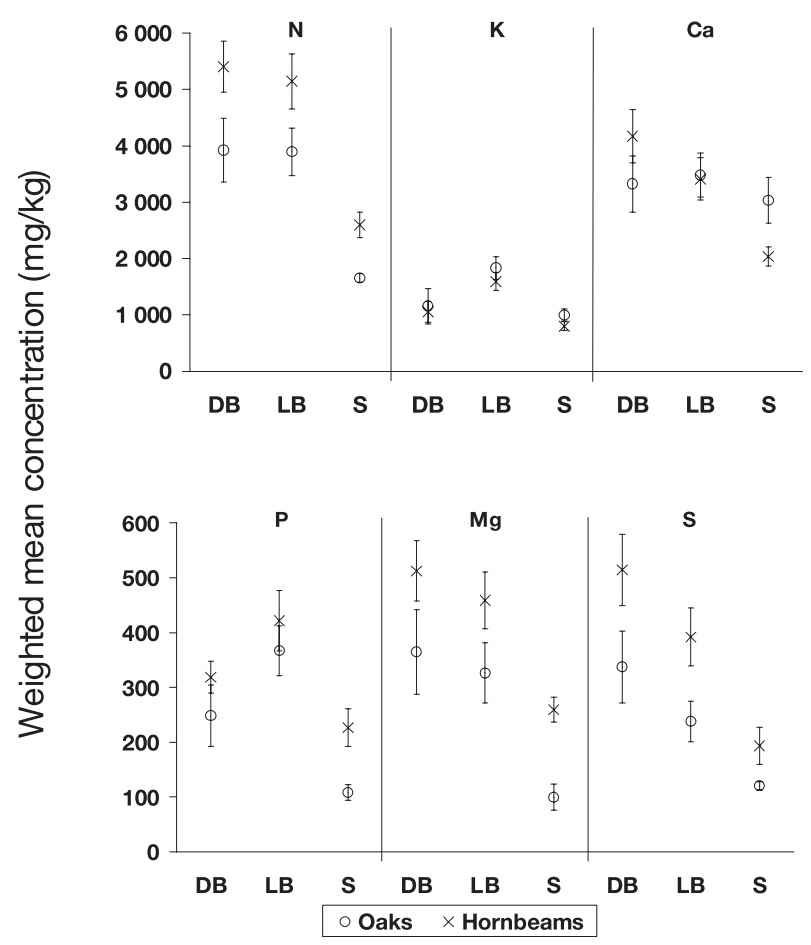

Figure 1. Dead branches (DB), live branches (LB) and stems (S) weighted mean concentrations in oaks and hornbeams. Error bars represent mean confidence intervals at level $\alpha=0.05$.

ponents; for $\mathrm{P}$ and $\mathrm{Ca}$, significant species effects are restricted to the stem.

For a given element, concentration patterns across those three compartments are generally similar for the two species. For both species, $\mathrm{K}$ and $\mathrm{P}$ mean concentrations in dead branches tend to be lower than in living branches. While the reverse trend is observed for $\mathrm{N}, \mathrm{S}, \mathrm{Mg}$ and $\mathrm{Ca}$ in hornbeam trees, the concentrations of both branch types are comparable for $\mathrm{N}$ and $\mathrm{Ca}$ in oaks. Note, however, that the differences in concentrations between both branch types are only significant for P. For a given element and species, stem concentrations are always the lowest ones.

\subsubsection{Tissue}

As previously stated, tissue separation is restricted to oak trees, and concerns both the stem and the three tickest branch classes (diameter $>7 \mathrm{~cm}$ ).

As shown in Table IV, the mean concentrations in oak stem tissues increase significantly for all nutrients according to: heartwood $<$ sapwood $<<$ bark. Concentration increase is highest between the two outer tissues, and is particularly sharp for calcium: Ca concentration in bark is almost 50 times that in sapwood, resulting in elevated (wood + bark) weighted average concentration of calcium compared to the other elements.

Based on their average concentrations, the ranking of the various nutrients is $\mathrm{N}>\mathrm{K}>\mathrm{Ca}>>\mathrm{P}, \mathrm{Mg}, \mathrm{S}$ in heartwood and 
Table IV. Average nutrient concentrations and $95 \%$ confidence intervals for stem oak tissues.

\begin{tabular}{lcccccc}
\hline Tissue & \multicolumn{6}{c}{ Nutrient concentration $(\mathrm{mg} / \mathrm{kg})$} \\
& $\mathrm{N}$ & $\mathrm{K}$ & $\mathrm{Ca}$ & $\mathrm{P}$ & $\mathrm{Mg}$ & $\mathrm{S}$ \\
\hline Heartwood & 951.4 & 494.0 & 354.2 & 12.1 & 17.5 & 84.9 \\
& \pm 41.3 & \pm 76.7 & \pm 47.0 & \pm 4.0 & \pm 8.9 & \pm 4.4 \\
Sapwood & 1868.3 & 1454.1 & 620.0 & 198.2 & 125.0 & 124.2 \\
& \pm 107.4 & \pm 92.3 & \pm 68.2 & \pm 24.0 & \pm 13.7 & \pm 11.8 \\
Wood weighted & 1227.6 & 806.4 & 435.4 & 70.6 & 52.1 & 96.8 \\
average & \pm 43.6 & \pm 95.9 & \pm 49.5 & \pm 12.1 & \pm 12.9 & \pm 6.3 \\
Bark & 6180.1 & 3035.5 & 30971.1 & 504.9 & 577.0 & 365.3 \\
& \pm 422.6 & \pm 301.6 & \pm 4806.3 & \pm 51.2 & \pm 114.9 & \pm 37.5 \\
Wood + bark & $\mathbf{1 6 5 3 . 9}$ & $\mathbf{9 9 6 . 9}$ & $\mathbf{3 0 3 1 . 8}$ & $\mathbf{1 0 8 . 1}$ & $\mathbf{9 9 . 4}$ & $\mathbf{1 2 0 . 4}$ \\
weighted average & $\pm \mathbf{7 6 . 5}$ & $\pm \mathbf{1 0 5 . 7}$ & $\pm \mathbf{4 0 8 . 4}$ & $\pm \mathbf{1 4 . 4}$ & $\pm \mathbf{2 3 . 9}$ & $\mathbf{\mathbf { 7 . 2 }}$ \\
\hline
\end{tabular}

sapwood, while in bark this would rather be $\mathrm{Ca} \gg>\mathrm{N}>\mathrm{K}>$ $\mathrm{P}, \mathrm{Mg}, \mathrm{S}$.

At the branch level (diameter $>7 \mathrm{~cm}$ ), the concentrations of all elements are significantly higher in bark than in wood.

\subsubsection{Tree size}

The effect of tree size on mean nutrient concentrations at the stem level was studied by means of regression equations, using several individual tree characteristics as predictors. As shown in Table $\mathrm{V}$, all selected relationships involve stem circumference at breast height (C130).
For oak trees, nutrient concentrations generally tend to decrease with an increase in circumference, except for $\mathrm{Ca}$ in both sapwood and bark, and for $\mathrm{N}$ in sapwood. $\mathrm{P}$ bark concentration shows a quadratic evolution with C130: it first diminishes with increasing $\mathrm{C} 130$ at low values and then tends to increase with a further increase in tree size. Based on adjusted $\mathrm{R}^{2}$ values, the effect of $\mathrm{C} 130$ on nutrient concentrations generally strengthens from heartwood to bark.

Mean $\mathrm{Mg}, \mathrm{N}$ and $\mathrm{P}$ concentrations in hornbeam boles are also influenced by $\mathrm{C} 130$, with a trend to decrease with increasing circumferences (Tab. V).

\subsubsection{Sampling height}

For both species and for each tissue in oak, significant relationships were found between nutrient concentrations at a given location in the stem and the corresponding distance to the crown. Other variables than distance to the crown, like stem circumference or tissue proportion at sampling level, were tested but did not result in any significant relationships with stem nutrient concentrations. For oaks as for hornbeams, mean stem nutrient concentrations may be affected by a tree effect, that was shown to be partly related to C130 (Tab. V), but that also likely depends on other factors not assessed in this study such as fertility variation at the plot scale, genetics, etc. This tree effect has thus been removed by subtracting the individual stem concentration calculated as the weighted average across all sampling levels from the corresponding concentration at the current sampling point; these "reduced" concentrations are called RedCc below.

Table V. Selected relationships between oak and hornbeam stem mean nutrient concentrations and circumference at breast height (C130).

\begin{tabular}{|c|c|c|c|c|c|c|c|}
\hline & \multirow[t]{2}{*}{ Nutrient } & \multicolumn{3}{|c|}{ Coefficients $^{(1)}$} & \multirow[t]{2}{*}{ Adj. $\mathrm{R}^{(2)}$} & \multirow[t]{2}{*}{$n^{(2)}$} & \multirow[t]{2}{*}{$P$} \\
\hline & & $\mathrm{a}$ & $\mathrm{b}$ & $\mathrm{c}$ & & & \\
\hline \multirow[t]{14}{*}{ Oaks } & \multicolumn{7}{|c|}{ Heartwood } \\
\hline & $\mathrm{P}$ & 24.06 & -0.09 & & 0.33 & 20 & $<0.0001$ \\
\hline & $\mathrm{Mg}$ & 26.61 & -0.10 & & 0.33 & 19 & $<0.0001$ \\
\hline & \multicolumn{7}{|c|}{ Sapwood } \\
\hline & $\mathrm{N}$ & 1490.42 & 3.04 & & 0.33 & 21 & $<0.0001$ \\
\hline & $\mathrm{Ca}$ & 366.78 & 1.84 & & 0.28 & 21 & $<0.0001$ \\
\hline & $\mathrm{Mg}$ & 193.99 & -0.47 & & 0.41 & 21 & $<0.0001$ \\
\hline & \multicolumn{7}{|c|}{ Bark } \\
\hline & $\mathrm{N}$ & 8038.58 & -13.54 & & 0.39 & 21 & $<0.0001$ \\
\hline & $\mathrm{K}$ & 3943.44 & -7.09 & & 0.20 & 21 & $<0.0001$ \\
\hline & $\mathrm{Ca}$ & 6769.67 & 180.07 & & 0.61 & 21 & $<0.0001$ \\
\hline & $\mathrm{P}$ & 462.67 & -0.18 & 0.03 & 0.32 & 21 & $<0.0001$ \\
\hline & $\mathrm{Mg}$ & 1108.27 & -4.04 & & 0.51 & 21 & $<0.0001$ \\
\hline & $\mathrm{S}$ & 518.07 & -1.09 & & 0.28 & 20 & $<0.0001$ \\
\hline \multirow[t]{3}{*}{ Hornbeams } & $\mathrm{N}$ & 3545.13 & -16.31 & & 0.53 & 17 & $<0.0001$ \\
\hline & $\mathrm{P}$ & 374.57 & -2.66 & & 0.41 & 17 & $<0.0001$ \\
\hline & $\mathrm{Mg}$ & 319.04 & -1.19 & & 0.48 & 16 & $<0.0001$ \\
\hline
\end{tabular}

(1) Model: concentration $=\mathrm{a}+\mathrm{b} \times \mathrm{C} 130+\mathrm{c} \times \mathrm{C} 130^{2}$, concentration expressed in $\mathrm{mg} / \mathrm{kg}$ and $\mathrm{C} 130$ ranging from 48 to $208 \mathrm{~cm}$ for oaks and from 10 to $77 \mathrm{~cm}$ for hornbeams.

(2) Observations numbers below 21 and 18 for oaks and hornbeams, respectively are due to exclusion of trees with incomplete data due to missing or erroneous values. 
Table VI. Relationships between oaks and hornbeams stem concentration $\left(\operatorname{RedC} c^{(1)}, \mathrm{mg} / \mathrm{kg}\right)$ and distance from the crown $\left(\operatorname{DistH} c^{(2)}, \mathrm{m}\right)$ or from the top $\left(\operatorname{DistHt}^{(3)}, \mathrm{m}\right)$.

\begin{tabular}{|c|c|c|c|c|c|c|c|c|}
\hline & \multirow{2}{*}{ Nutrient } & \multicolumn{4}{|c|}{ Coefficients } & \multirow{2}{*}{ Adj. $R^{2}$} & \multirow{2}{*}{$n^{(4)}$} & \multirow{2}{*}{$P$} \\
\hline & & $\mathrm{a}$ & $\mathrm{b}$ & $\mathrm{c}$ & $\mathrm{d}$ & & & \\
\hline \multirow[t]{21}{*}{ Oaks } & \multicolumn{8}{|c|}{ Heartwood } \\
\hline & $\mathrm{N}^{(5)}$ & 88.06 & -16.31 & & & 0.39 & 128 & $<0.0001$ \\
\hline & $\mathrm{K}^{(5)}$ & 82.29 & -16.33 & & & 0.24 & 167 & $<0.0001$ \\
\hline & $\mathrm{Ca}^{(5)}$ & - & - & - & & - & & \\
\hline & $\mathrm{P}^{(6)}$ & 4.68 & -0.04 & & & 0.20 & 168 & $<0.0001$ \\
\hline & $\mathrm{Mg}^{(6)}$ & 4.69 & -0.04 & & & 0.14 & 161 & $<0.0001$ \\
\hline & $S^{(5)}$ & 3.88 & -0.65 & & & 0.10 & 175 & $<0.0001$ \\
\hline & \multicolumn{8}{|c|}{ Sapwood } \\
\hline & $\mathrm{N}^{(5)}$ & 29.16 & -5.83 & & & 0.03 & 132 & $<0.0001$ \\
\hline & $\mathrm{K}^{(5)}$ & 183.36 & -23.54 & -5.85 & 0.50 & 0.30 & 178 & $<0.0001$ \\
\hline & $\mathrm{Ca}^{(5)}$ & - & - & - & & - & & \\
\hline & $\mathrm{P}^{(5)}$ & 15.01 & -5.19 & 0.28 & & 0.14 & 170 & $<0.0001$ \\
\hline & $\mathrm{Mg}^{(6)}$ & 5.14 & -0.25 & & & 0.40 & 179 & $<0.0001$ \\
\hline & $S^{(5)}$ & - & - & - & & - & & \\
\hline & \multicolumn{8}{|c|}{ Bark } \\
\hline & $\mathrm{N}^{(5)}$ & 249.49 & -43.48 & & & 0.19 & 131 & $<0.0001$ \\
\hline & $\mathrm{K}^{(5)}$ & -148.89 & 26.18 & & & 0.08 & 170 & $<0.0001$ \\
\hline & $\mathrm{Ca}^{(5)}$ & -3192.39 & 541.04 & & & 0.41 & 179 & $<0.0001$ \\
\hline & $\mathrm{P}^{(5)}$ & 17.59 & -3.09 & & & 0.09 & 178 & $<0.0001$ \\
\hline & $\mathrm{Mg}^{(5)}$ & - & - & - & & - & & \\
\hline & $S^{(5)}$ & 17.47 & -2.74 & & & 0.10 & 176 & $<0.0001$ \\
\hline \multirow[t]{6}{*}{ Hornbeams } & $\mathrm{N}^{(6)}$ & 8.35 & -0.82 & & & 0.53 & 138 & $<0.0001$ \\
\hline & $\mathrm{K}^{(6)}$ & 6.62 & -0.25 & & & 0.21 & 139 & $<0.0001$ \\
\hline & $\mathrm{Ca}^{(5)}$ & 1111.35 & -25.00 & & & 0.12 & 145 & $<0.0001$ \\
\hline & $\mathrm{P}^{(6)}$ & 5.84 & -0.31 & & & 0.51 & 141 & $<0.0001$ \\
\hline & $\mathrm{Mg}^{(6)}$ & 5.21 & -0.36 & & & 0.40 & 138 & $<0.0001$ \\
\hline & $S^{(6)}$ & 5.59 & -0.16 & & & 0.35 & 133 & $<0.0001$ \\
\hline
\end{tabular}

(1) See in the text for additional information on RedCc.

(2) DistHc = Hc-sampling height, thus decreasing as we get closer to the crown; range (m): $[-4.82,14.00]$ (oaks).

(3) $\mathrm{DistHt}=\mathrm{Ht}$-sampling height, thus decreasing as we get closer to the crown; range $(\mathrm{m})$ : $[0.10,18.90]$ (hornbeams).

(4) Differences between observation numbers result from missing or erroneous values.

(5) Model: RedCc $=\mathrm{a}+\mathrm{b} \times \mathrm{y}+\mathrm{c} \times \mathrm{y}^{2}+\mathrm{d} \times \mathrm{y}^{3}$, where $\mathrm{y}=\mathrm{Hc}$ (oaks) or Ht (hornbeams).

(6) Model: Oaks: $\log \left(\operatorname{RedCc}^{\prime}\right)=\mathrm{a}+\mathrm{b} \times \log \left(\right.$ DistHc' $^{\prime}$, Hornbeams: $\log \left(\operatorname{RedCc}^{\prime}\right)=\mathrm{a}+\mathrm{b} \times \log \left(\right.$ DistHt' $\left.^{\prime}\right)$; Oaks: RedCc' $=$ RedCc +100 and DistHc' $=$ DistHc + 5; Hornbeams: RedCc' $=$ RedCc $+\mathrm{X}$, with $\mathrm{X}=1100$ for $\mathrm{N}, \mathrm{X}=500$ for $\mathrm{K}, \mathrm{X}=100$ for $\mathrm{Mg}, \mathrm{X}=200$ for P, S. These transformations are needed to get positive values for log arguments.

For oaks, various measures of distance to the crown could be used: distance from the sampling level to (i) the top of the tree (DistHt), (ii) the widest crown lateral development (Dis$t H c$ ) or (iii) the insertion point of the lowest living branch (Dis$t H l b)$. The last distance only showed weak correlations with "reduced" concentrations, contrary to the first two ones. Due to generally higher adjusted $\mathrm{R}^{2}$ values, DistHc was finally selected. The most significant relationships are shown in Table VI. Concentrations generally tend to decrease with increasing Dis$t H c$, that is with increasing distance from the crown. For phosphorus in sapwood, quadratic patterns result in declining $\mathrm{P}$ concentrations with increasing DistHc across most of the investigated range, except at high values. $\mathrm{P}$ and $\mathrm{Mg}$ in heartwood and $\mathrm{Mg}$ concentrations in sapwood decrease exponen- tially with distance from the crown, whereas $\mathrm{K}$ in sapwood follows a cubic polynomial pattern. $\mathrm{K}$ and $\mathrm{Ca}$ in bark are the only two cases of continuous increasing concentrations with Dist Hc.

Hornbeam "reduced" stem concentrations $(\operatorname{Red} C c)$ decrease exponentially with increasing Dist Ht for all nutrients except $\mathrm{Ca}$, whose concentration decreases linearly with an increase in the predictor value (Tab. VI).

\subsubsection{Branch diameter}

The effect of branch diameter on the average concentrations of woody tissues (wood + bark) is illustrated in Figure 2. The general trend is characterised by a decrease of the nutrient concentrations from the thinner living branches (diameter $<1 \mathrm{~cm}$, 

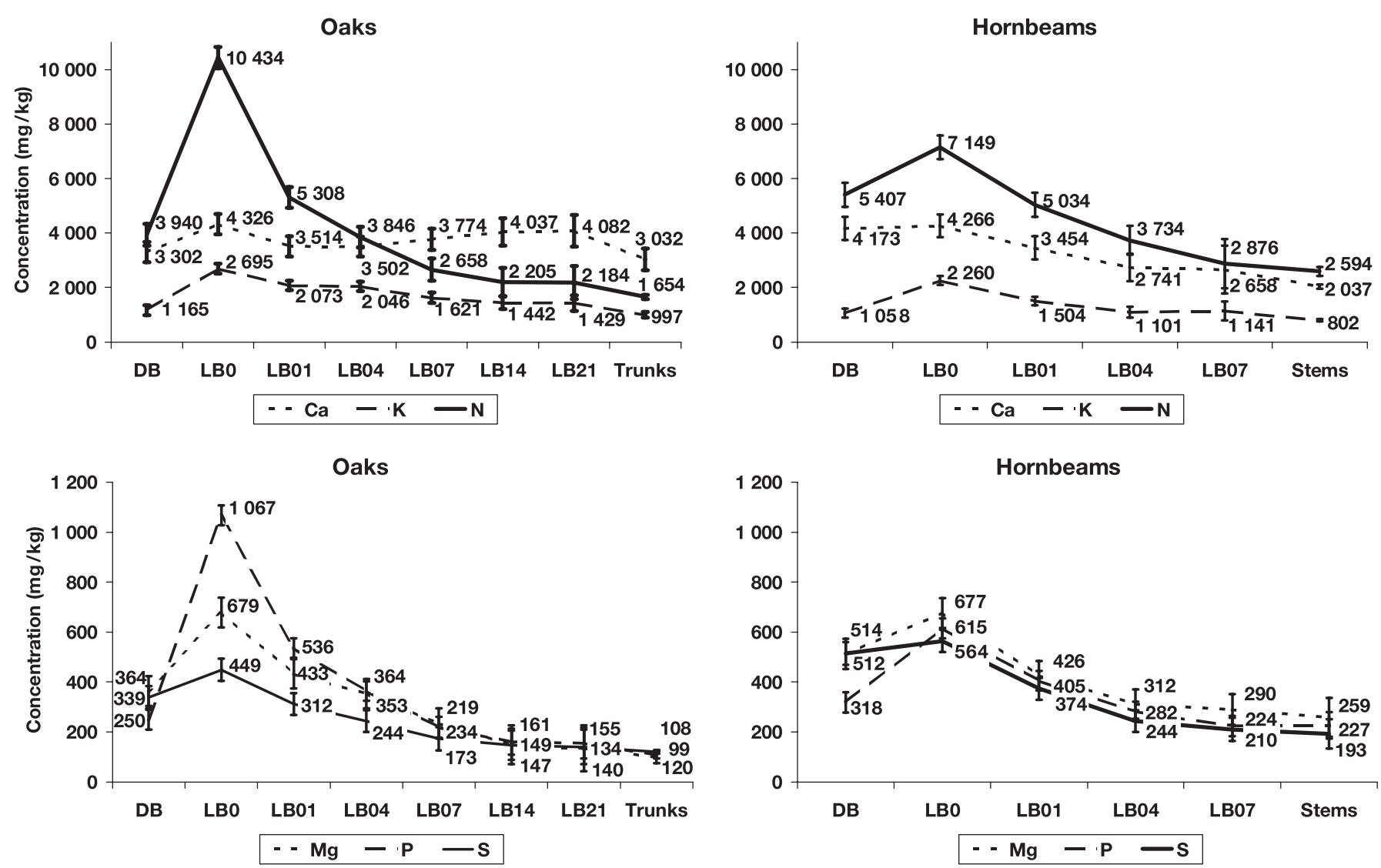

Figure 2. Comparison of mean concentrations between components, for oaks (a) and hornbeams (b) trees. DB: dead branches; LB: live branches (0: diameter < 1 cm; 01: 1-4 cm; 04: 4-7 cm; 07: 7-14 cm; 14: 14-21 cm; 21: > $21 \mathrm{~cm}$ ); S: stems Ca, K, N: upper part; Mg, P, S: lower part. Error bars represent mean confidence intervals at level $\alpha=0.05$.

LB0) towards the thicker ones (diameter $>21 \mathrm{~cm}, \mathrm{LB} 21)$, the latter showing concentrations comparable to those observed in the stems; differences in nutrient concentrations between successive live branch classes become less and less significant as branch diameter increases. Calcium concentrations in oak are an exception to this pattern: they tend to increase, although not significantly, with the diameter of the thicker branches while they decrease significantly from LB0 to LB01. The increase in bulk $\mathrm{Ca}$ concentrations with increasing branch diameter is explained by a corresponding increase in bark Ca concentrations at constant wood $\mathrm{Ca}$ concentrations. For each element, the ratio between the mean concentrations in the smallest (LB0) and the tickest (LB21) branches is higher and more variable for the oak trees than for the hornbeams; it ranges from $1.9(\mathrm{~K})$ to $6.9(\mathrm{P})$ in oaks, and from $2.1(\mathrm{Ca})$ to $2.9(\mathrm{~S})$ in hornbeams. In absolute terms, the difference in concentration between LB0 and LB21 categories is particularly strong for nitrogen in oaks where it amounts to about $8000 \mathrm{ppm}$.

The difference in mean concentrations between dead and live branches is nutrient dependent. Except for $\mathrm{K}$ in both species and for $\mathrm{Ca}$ in oak, mean dead branch concentrations are within the range of mean live branch concentrations.

For both species, the three high-level nutrients are ranked according to $\mathrm{N}>\mathrm{Ca}>\mathrm{K}$ for all components except in oak branches thicker than $7 \mathrm{~cm}$ where the order is $\mathrm{Ca}>\mathrm{N}>\mathrm{K}$.
Mean concentrations of the three other nutrients are very similar for a given species and live branch category, except in the thinner branches of oaks where $\mathrm{P}>\mathrm{Mg}>\mathrm{S}$.

\subsection{Biomass and nutrient content}

As previously stated, the biomass and nutrient content of the various components and tissues were predicted by means of linear regression models, using circumference at breast height, total tree height, and/or mean crown radius as predictors. Highly significant linear relationships also existed between stem or total tree biomass or nutrient content and stem volume, computed from all stem sections using the Newton's formula. All regression equations are available on request to the authors.

\subsubsection{Tree level}

For both species, power models were generally the best to explain the evolution of total or compartment tree biomass or nutrient content as a function of stem circumference at breast height. Relative differences between measurements and estimates were generally lower than $10 \%$ when $\mathrm{C} 130$ was used as the independent variable, and lower than $20 \%$ in the other cases. Moreover, the sum of separate estimates of each compartment differed from direct total tree estimation by less than $10 \%$ in most cases. Figure 3 presents the estimated contribution of the 


\section{OAKS}

Total individual biomass $(\mathbf{k g})$

$120 \quad 270 \quad 480 \quad 77511501600215028003550$

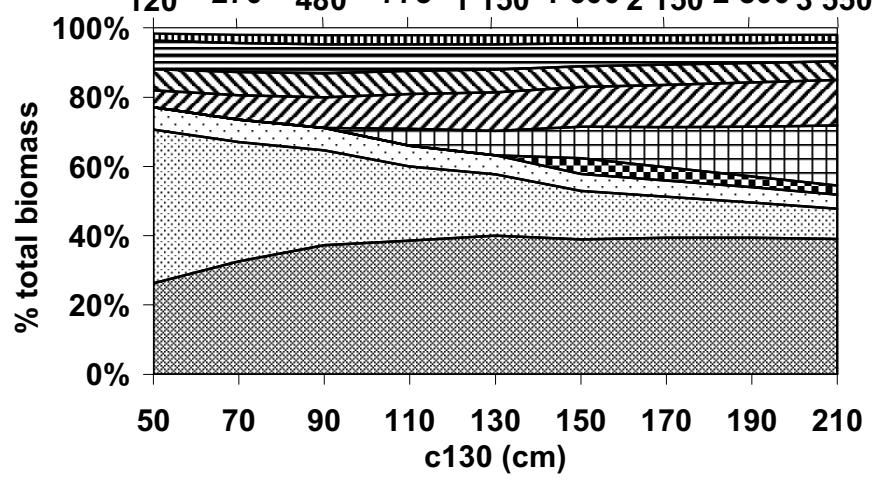

$\mathbf{N}$ total individual nutrient content $(\mathrm{g})$

$340720 \quad 1260197028403900514065808200$

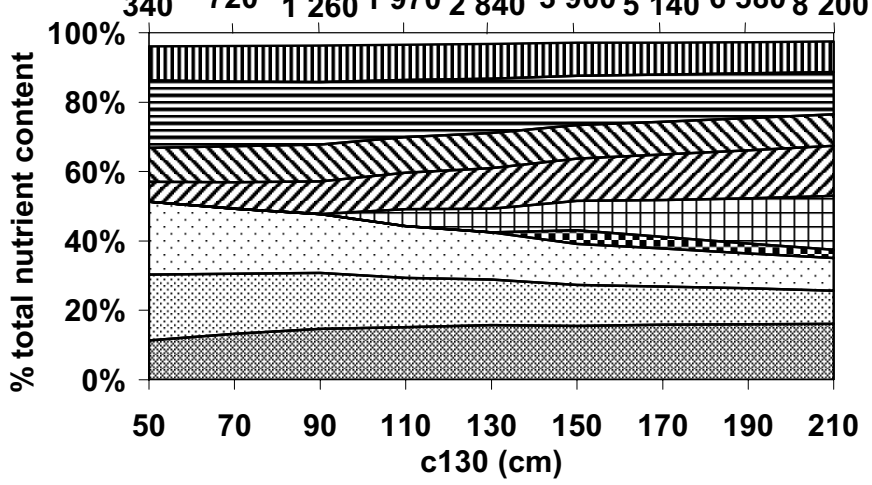

$\mathrm{K}$ total individual nutrient content (g)

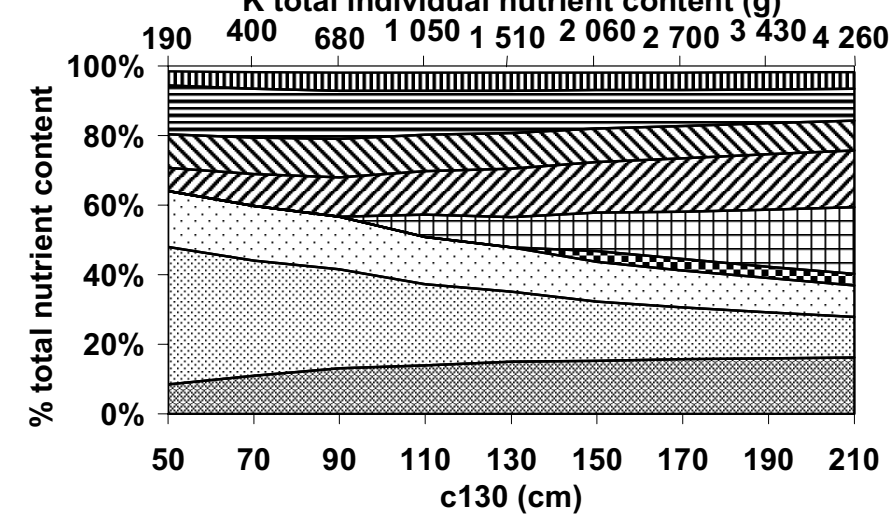

$P$ total individual nutrient content $(\mathrm{g})$

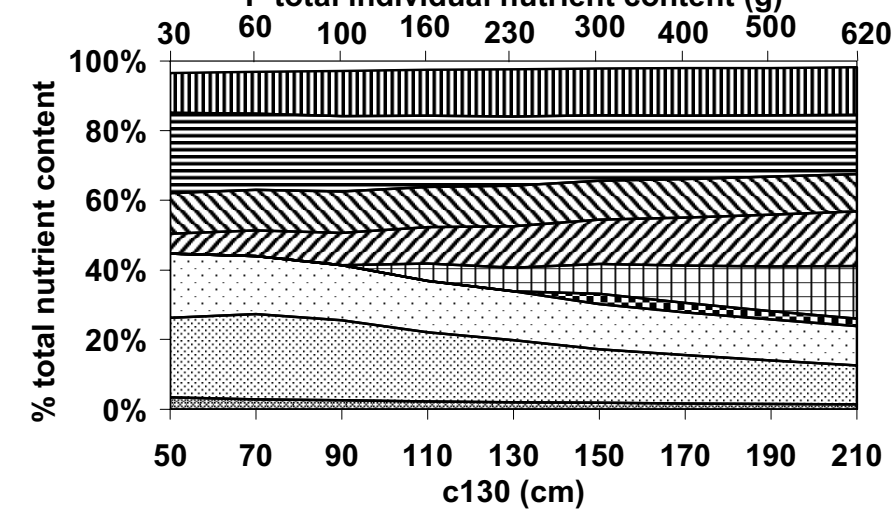

HORNBEAMS
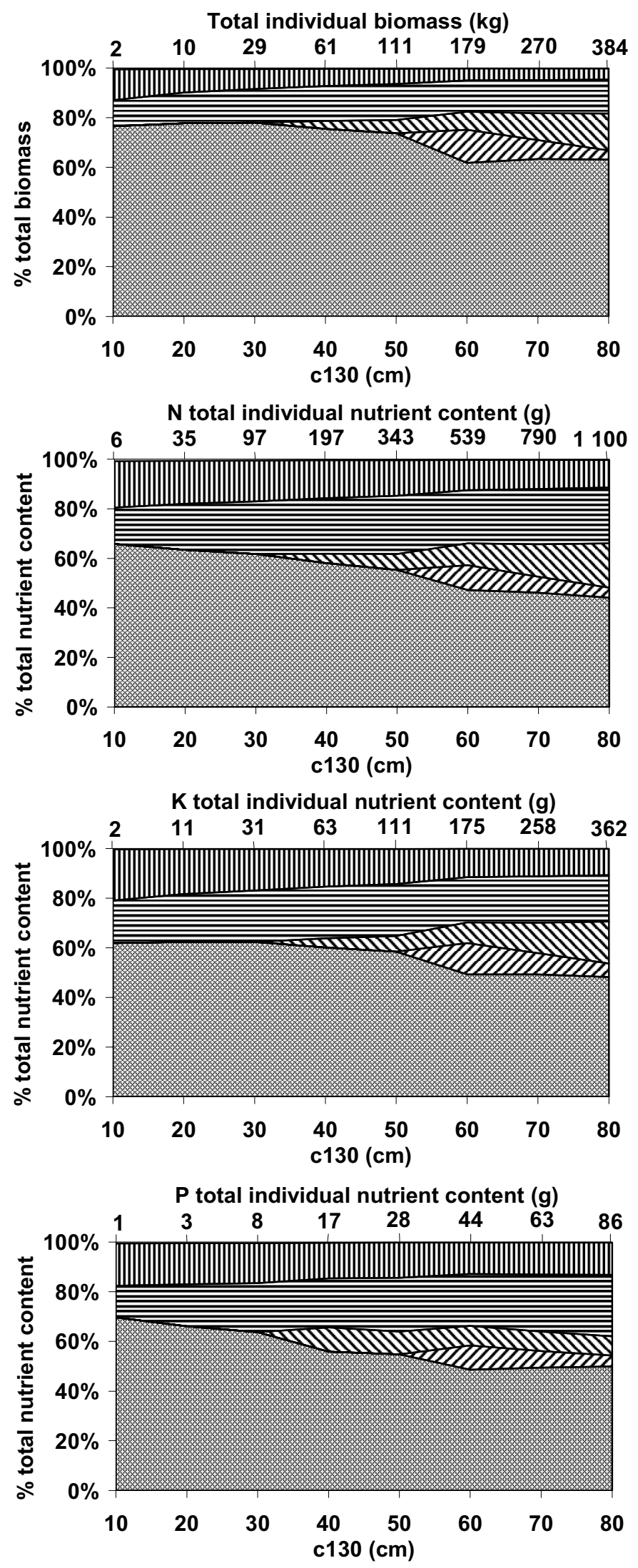

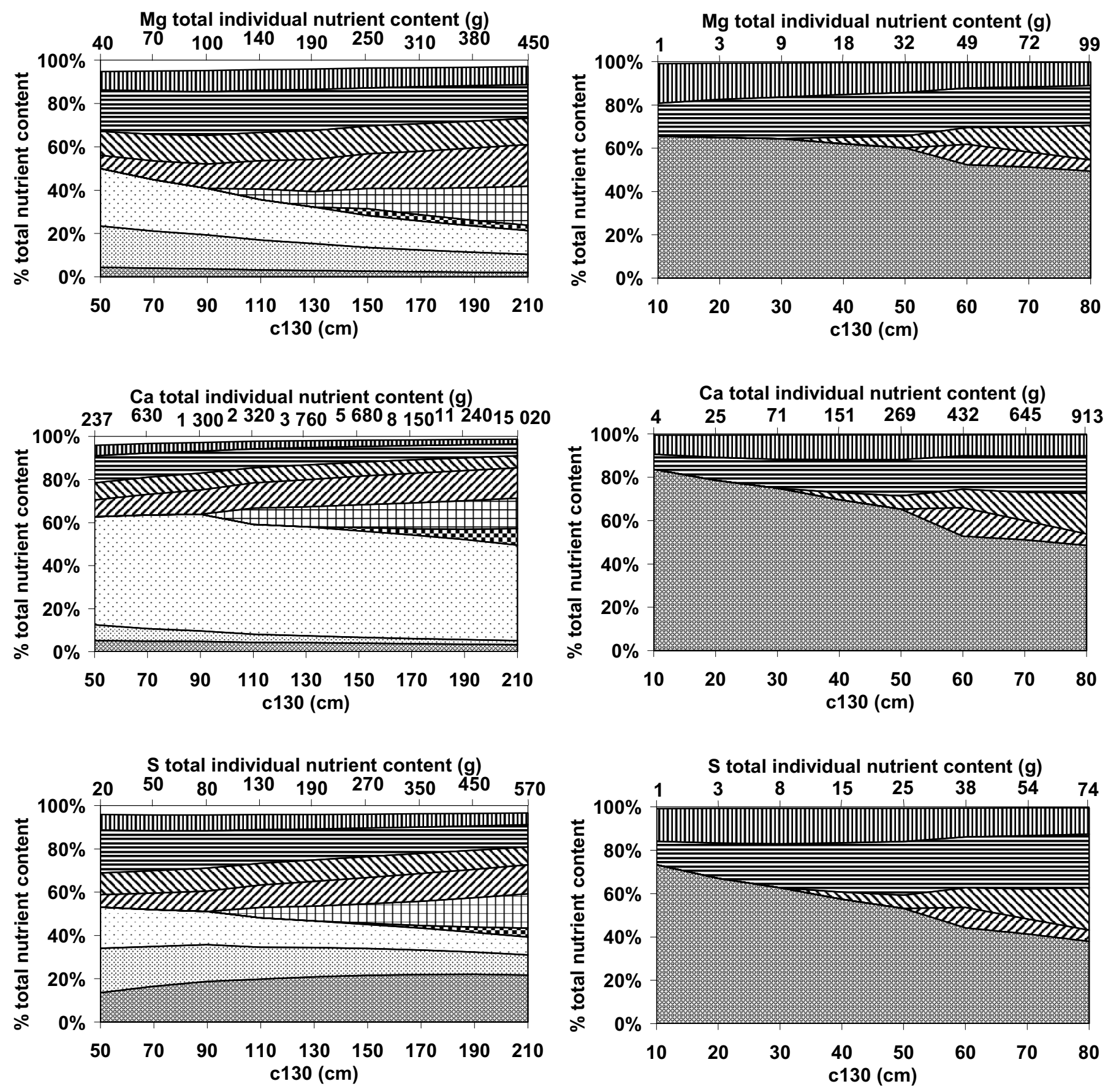

\begin{tabular}{|c|c|c|}
\hline Heartwood/Stem & Sapwood & Bark \\
\hline Q LB(>21cm) & $\boxplus \mathrm{LB}(14-21 \mathrm{~cm})$ & $\mathbb{Z} \mathrm{LB}(7-14 \mathrm{~cm})$ \\
\hline $\begin{array}{l}\mathbb{N} \text { LB(4-7cm) } \\
\square \text { DB }\end{array}$ & 夆 $\mathrm{LB}(1-4 \mathrm{~cm})$ & $\mathbb{\| l l |} \mid \mathrm{LB}(<1 \mathrm{~cm})$ \\
\hline
\end{tabular}

Figure 3. Evolution of estimated individual tree biomass and nutrient content distribution in oaks and hornbeams, as a function of circumference at $1.30 \mathrm{~m}(\mathrm{c} 130)$. Total tree estimates are also given for each tree size. 
various components to total individual tree biomass or nutrient content as a function of circumference at breast height; tissues are only distinguished for oak stems. Total tree estimates are also given for each tree size.

For the range of circumferences considered in this study, estimates of total individual biomass vary from $120 \mathrm{~kg}$ to $3550 \mathrm{~kg}$, and from $2 \mathrm{~kg}$ to $384 \mathrm{~kg}$ for the oaks and hornbeams, respectively (Fig. 3).

Oak stem biomass ranges from $55 \%$ of total individual biomass in the biggest trees to $80 \%$ of it in the thinner ones; the difference of biomass distribution between trees of various sizes is mainly due to the increasing contribution of the thicker branches (LB14 and LB21) with stem circumference. The proportion of each thinner branch class (diameter $<7 \mathrm{~cm}$ ) in total individual biomass remains rather constant across the investigated circumference classes. Concerning stem tissues, heartwood and sapwood proportions tend to increase and decrease, respectively, with stem circumference, this being considered relative to either total tree or stem biomass; heartwood makes up to $75 \%$ of stem biomass in the biggest tree. On the other hand, the contribution of bark is about $10 \%$ of stem biomass for all girths classes.

Within the investigated $\mathrm{C} 130$ range, the contribution of hornbeam individual stem biomass to total tree decreases sharply from more than $75 \%$ to about $60 \%$ at a C130 $\geq 60 \mathrm{~cm}$; beyond this value, stem biomass proportion remains rather constant. Crown biomass of the smallest $(\mathrm{C} 130 \leq 30 \mathrm{~cm}) \mathrm{sam}-$ pled hornbeams is shared equally between LB0 and LB1 branch categories.

The pattern of nutrient distribution between the various components as a function of $\mathrm{C} 130$ (Fig. 3) is explained both by the relative concentrations of the different compartments as well as by their relative contribution to total tree biomass as a function of tree dimension (Tab. V and Fig. 3).

In oak stems, the contribution of heartwood and sapwood to total tree amounts is generally much lower for nutrient contents than for biomass (Fig. 3). The reverse trend is observed for bark: the minimum contribution of bark to total tree nutrient content amounts to $9 \%$ for $\mathrm{S}$ and $\mathrm{K}$, compared to a maximal biomass proportion of $8 \%$. The proportion of oak crown nutrient content in total tree amounts is higher than expected on a biomass basis for $\mathrm{N}, \mathrm{P}, \mathrm{K}, \mathrm{Mg}$, and $\mathrm{S}$; by contrast, the contribution of crown to the total is comparable for both $\mathrm{Ca}$ and biomass across most part of the investigated circumference range.

In the hornbeam trees, the proportion of nutrients associated to the crown increases with an increase in C130, from less than $40 \%$ at a stem diameter of $10 \mathrm{~cm}$, up to a maximum of $60 \%$ at a $\mathrm{C} 130$ of $80 \mathrm{~cm}$.

\subsubsection{Stand level}

Assessment of biomass and nutrient content at the stand level (Tab. VII) was performed for the level II plot of Chimay (Tab. II) using established models.

Total stand biomass amounts to $191.3 t \mathrm{ha}^{-1}$ (Tab. VII). The partitioning between oaks $(80.7 \%)$ and hornbeams $(19.3 \%)$ is consistent with the corresponding basal areas and mean tree dimensions of both species in the stand (Tab. II).
Stems, which represent $55 \%$ of total oak biomass, consist for $71 \%, 21 \%$ and $8 \%$ of heartwood, sapwood and bark, respectively. LB14 and LB07 are the dominant branch classes, and account together for $55 \%$ of oak total branch biomass. At the coppice level, stems amount to $74 \%$ of total biomass; with $80 \%$ of total crown woody biomass, the thinner LB0 and LB 1 categories are the dominant branch classes.

Total stand nutrient content ranges from $39 \mathrm{~kg} \mathrm{ha}^{-1}$ for $\mathrm{P}$ to $690 \mathrm{~kg} \mathrm{ha}^{-1}$ for Ca (Tab. VII). Despite the generally higher mean concentrations in hornbeams components (Fig. 1), the fraction of total stand content associated with oaks is dominant for all elements, and ranges from $67 \%$ for $\mathrm{Mg}$ to $84 \%$ or more for $\mathrm{K}$ and $\mathrm{Ca}$. $\mathrm{Ca}$ distribution within oaks is particularly remarkable with $89 \%$ of oak stem content (i.e. $41 \%$ of total stand $\mathrm{Ca}$ content or $284 \mathrm{~kg} \mathrm{ha}^{-1}$ ) included in bark tissues, yet the contribution of the latter to total oak biomass is less than $5 \%$. The partitioning of nutrients between stems and branches differs among species. In hornbeam trees, all nutrients are preferentially associated with stem components; the reverse trend is observed for the oaks for all elements, except $\mathrm{Ca}$. The pattern of nutrient content partitioning between stems and branches is similar among elements for the hornbeams (stem nutrient proportion around $60 \%$ ), whereas quite contrasting patterns are observed for the oaks (proportion of total tree nutrient content in the stems ranging from $25 \%$ for $\mathrm{Mg}$ up to $53.4 \%$ for $\mathrm{Ca}$ ). From $75 \%$ to $80 \%$ of total stand oak crown woody nutrient contents are shared among branch classes LB1 to LB14; $\mathrm{Ca}$ is here again an exception with more than $55 \%$ of it included in the two LB7 and LB14 categories.

For the hornbeams, the thinnest living branches (LB0 and LB1) include more than $80 \%$ of total crown element content for each nutrient, as a result of both the low biomass proportion and the low nutrient concentrations of the thicker branches.

\section{DISCUSSION AND CONCLUSIONS}

\subsection{Nutrient concentrations}

\subsubsection{Nutrient and species}

Higher concentrations of $\mathrm{N}, \mathrm{K}$ and $\mathrm{Ca}$ in woody tissues in comparison with $\mathrm{P}, \mathrm{Mg}$ and $\mathrm{S}$ (Tab. IV and Fig. 1) were already noticed for both species in several studies [8, 10, 20]. Differences in nutrient concentrations between oaks and hornbeams were found for all nutrients except $\mathrm{K}$ in this study; such species related differences were also reported by Duvigneaud et al. [10] and suggest a possible discriminant effect of species on the chemical composition of tree components [19]. However, part of these apparent "species" differences could result from the contrasting ranges of age and/or dimensions between the species (Tab. III), as those parameters were shown to influence nutrient concentrations (Tab. V).

\subsubsection{Tissue}

Many authors observed nutrient concentration differences between oak tissues. Studies concerning the radial evolution of 
Table VII. Estimation of biomass and nutrient contents in the level II oak-hornbeam stand of Chimay(1).

\begin{tabular}{|c|c|c|c|c|c|c|c|c|c|c|c|c|c|c|c|}
\hline \multirow[t]{2}{*}{ Species } & \multirow[t]{2}{*}{ Compartment } & \multicolumn{2}{|c|}{ Biomass (t/ha) } & \multicolumn{12}{|c|}{ Nutrient contents $(\mathrm{kg} / \mathrm{ha})$} \\
\hline & & & $\%$ & $\mathrm{~N}$ & $\%$ & $\mathrm{~K}$ & $\%$ & $\mathrm{P}$ & $\%$ & $\mathrm{Mg}$ & $\%$ & $\mathrm{Ca}$ & $\%$ & $\mathrm{~S}$ & $\%$ \\
\hline \multirow[t]{13}{*}{ Oaks } & Heartwood & 60.2 & 39.0 & 58.5 & 15.4 & 29.3 & 15.3 & 0.5 & 1.7 & 0.5 & 2.4 & 22.1 & 3.7 & 5.3 & 21.5 \\
\hline & Sapwood & 18.0 & 11.7 & 40.7 & 10.7 & 29.9 & 15.6 & 3.9 & 13.6 & 2.3 & 10.0 & 14.7 & 2.4 & 2.7 & 10.9 \\
\hline & Bark & 7.1 & 4.6 & 40.3 & 10.6 & 19.3 & 10.0 & 3.4 & 11.8 & 3.0 & 13.0 & 284.4 & 47.3 & 2.3 & 9.4 \\
\hline & Tot. stems & 85.3 & 55.3 & 139.5 & 36.7 & 78.4 & 40.9 & 7.7 & 27.0 & 5.8 & 25.4 & 321.2 & 53.4 & 10.3 & 41.8 \\
\hline & LB21 & 5.4 & 3.5 & 11.8 & 3.1 & 7.6 & 4.0 & 0.8 & 2.8 & 0.8 & 3.6 & 24.2 & 4.0 & 1.1 & 4.4 \\
\hline & LB14 & 19.3 & 12.5 & 43.1 & 11.3 & 26.7 & 13.9 & 3.1 & 10.8 & 2.8 & 12.4 & 73.9 & 12.3 & 2.9 & 11.8 \\
\hline & LB7 & 18.6 & 12.1 & 49.8 & 13.1 & 28.4 & 14.8 & 4.1 & 14.2 & 3.9 & 17.0 & 80.2 & 13.3 & 3.2 & 12.8 \\
\hline & LB4 & 8.9 & 5.8 & 35.1 & 9.2 & 18.4 & 9.6 & 3.2 & 11.1 & 2.8 & 12.3 & 37.0 & 6.2 & 2.1 & 8.5 \\
\hline & LB1 & 9.9 & 6.4 & 52.5 & 13.8 & 19.3 & 10.0 & 5.3 & 18.7 & 3.9 & 16.9 & 39.9 & 6.6 & 2.8 & 11.3 \\
\hline & LB0 & 3.6 & 2.4 & 37.1 & 9.8 & 9.5 & 5.0 & 3.8 & 13.3 & 2.1 & 9.1 & 16.6 & 2.8 & 1.5 & 5.9 \\
\hline & DB & 3.2 & 2.1 & 10.9 & 2.9 & 3.4 & 1.8 & 0.6 & 2.1 & 0.7 & 3.3 & 9.0 & 1.5 & 0.9 & 3.6 \\
\hline & Tot. branches & 69.0 & 44.7 & 240.2 & 63.3 & 113.4 & 59.1 & 20.9 & 73.0 & 17.1 & 74.6 & 280.7 & 46.6 & 14.4 & 58.2 \\
\hline & Tot. oaks & 154.4 & 80.7 & 379.7 & 76.2 & 191.8 & 84.0 & 28.6 & 74.3 & 23.0 & 67.1 & 601.9 & 87.3 & 24.8 & 74.1 \\
\hline \multirow[t]{9}{*}{ Hornbeams } & Stems & 27.5 & 74.4 & 68.7 & 58.1 & 21.4 & 58.7 & 5.9 & 59.6 & 6.9 & 61.6 & 55.0 & 62.7 & 5.0 & 57.6 \\
\hline & LB7 & 0.5 & 1.3 & 1.1 & 0.9 & 0.4 & 1.2 & 0.1 & 0.8 & 0.1 & 0.8 & 0.9 & 1.1 & 0.1 & 0.8 \\
\hline & LB4 & 1.3 & 3.5 & 4.7 & 4.0 & 1.4 & 3.8 & 0.4 & 3.7 & 0.4 & 3.4 & 3.3 & 3.7 & 0.3 & 3.5 \\
\hline & LB1 & 5.0 & 13.6 & 25.6 & 21.6 & 7.5 & 20.6 & 2.0 & 20.2 & 2.1 & 19.0 & 17.4 & 19.9 & 1.9 & 21.6 \\
\hline & LB0 & 2.5 & 6.8 & 17.6 & 14.9 & 5.6 & 15.3 & 1.5 & 15.3 & 1.6 & 14.7 & 10.5 & 12.0 & 1.4 & 15.8 \\
\hline & DB & 0.1 & 0.4 & 0.6 & 0.5 & 0.1 & 0.3 & 0.0 & 0.4 & 0.1 & 0.5 & 0.5 & 0.5 & 0.1 & 0.7 \\
\hline & Tot. branches & 9.4 & 25.6 & 49.6 & 41.9 & 15.0 & 41.3 & 4.0 & 40.4 & 4.3 & 38.4 & 32.7 & 37.3 & 3.7 & 42.4 \\
\hline & Tot. hornbeams & 36.9 & 19.3 & 118.3 & 23.8 & 36.4 & 16.0 & 9.9 & 25.7 & 11.2 & 32.9 & 87.7 & 12.7 & 8.7 & 25.9 \\
\hline & Tot. stand & 191.3 & 100 & 498.0 & 100 & 228.2 & 100 & 38.5 & 100 & 34.2 & 100 & 689.5 & 100 & 33.4 & 100 \\
\hline
\end{tabular}

(1) LB: live branches (0: diameter < $1 \mathrm{~cm}$; 1: 1-4 cm; 4: 4-7 cm; 7: 7-14 cm; 14: 14-21 cm; 21: > $21 \mathrm{~cm}$ ); DB: dead branches.

nutrient concentration in oak rings $[8,17,23]$ reported a sharp increase in the transition zone from heartwood to sapwood for all or part of the six nutrients considered here. According to Bamber and Fukazawa [3], this transition may be interpreted as a nutrient resorption from senescing sapwood rings to cells of younger ones. Mussche et al. [20], however, observed decreasing $\mathrm{P}$ concentrations from heartwood to sapwood. Nutrient concentrations previously reported for heartwood and sapwood are generally close to ours except values from Lévy et al. [17] which are systematically higher; according to these researchers, heartwood concentration would reflect soil chemical properties evolution while sapwood concentrations would rather result from nutrient translocations occurring between rings.

Very high concentrations of $\mathrm{Ca}$ in oak stem bark were also mentioned by Mussche et al. [20] and De Visser [8]; our values are however about twice higher and reach those measured by Duvigneaud et al. [10] for a mixed oak, beech and hornbeam - broadleaved forest growing on a calcareous soil in Virelles (Belgium). High $\mathrm{Ca}$ bark concentrations, also reported for other species by various authors, would result from immobilisation of this nutrient during cell wall lignification $[1,6]$.

\subsubsection{Tree size and sampling level}

Concerning tree size effect, Nys et al. [21] observed significant relationships between $\mathrm{P}$ and $\mathrm{Ca}$ concentration in oak bark and $\mathrm{C} 130$; in their study, however, $\mathrm{P}$ and $\mathrm{Ca}$ showed similar trends with $\mathrm{C} 130$. Because the present stand is a coppice-withstandards, the difference in $\mathrm{C} 130$ between oak trees partly reflect contrasting age classes. In this context, the relationships between nutrient concentrations and circumference for a given component as observed here can be interpreted in terms of internal transfers of $\mathrm{K}, \mathrm{N}$ and $\mathrm{P}$ towards young tissues and accumulation of $\mathrm{Ca}$ in older ones [5].

In oak heartwood and sapwood, the concentrations of most elements tended to decrease with increasing DistHc; in oak bark, $\mathrm{K}$ and $\mathrm{Ca}$ elements accumulated towards the base of tree trunks. For hornbeams, "reduced" stem concentrations $(\operatorname{Red} C \mathrm{c})$ decreased from tree top to base, for all elements (Tab. VI). The position of a sample relative to the crown of a given tree also reflects its relative mean age. The regressions between tissue concentrations and various measurements of crown distance can thus also express a tissue mean age effect, the latter decreasing with decreasing distance from the crown. 
Table VIII. Biomass and nutrient contents in the Chimay coppice-with-standards stand compared with selected literature data ${ }^{(1)}$.

\begin{tabular}{|c|c|c|c|c|c|c|c|c|c|c|c|c|}
\hline Region & Species & $\begin{array}{c}\text { Age } \\
\text { (years) }\end{array}$ & $\begin{array}{l}\text { Htot } \\
(\mathrm{m})\end{array}$ & $\begin{array}{c}\text { Basal area } \\
\left(\mathrm{m}^{2} / \mathrm{ha}\right)\end{array}$ & $\begin{array}{l}\text { Biomass } \\
(\mathrm{t} / \mathrm{ha})\end{array}$ & $\begin{array}{c}\mathrm{N} \\
(\mathrm{kg} / \mathrm{ha})\end{array}$ & & $\begin{array}{c}\mathrm{K} \\
(\mathrm{kg} / \mathrm{ha})\end{array}$ & & $\begin{array}{c}\mathrm{P} \\
(\mathrm{kg} / \mathrm{ha})\end{array}$ & $\begin{array}{c}\mathrm{Mg} \\
(\mathrm{kg} / \mathrm{ha})\end{array}$ & $\begin{array}{c}\mathrm{Ca} \\
(\mathrm{kg} / \mathrm{ha})\end{array}$ \\
\hline \multirow[t]{3}{*}{$\begin{array}{l}\text { Château- } \\
\text { Regnault }^{(2)}\end{array}$} & $\begin{array}{l}\text { Quercus petraea } \\
\text { Fagus sylvatica }\end{array}$ & 150 & - & - & 90.0 & $274(3.0)$ & 121 & $(1.3)$ & 15 & $(0.2)$ & $11(0.1)$ & $127(1.4)$ \\
\hline & $\begin{array}{l}\text { Sorbus aucuparia } \\
\text { Betula verrucosa }\end{array}$ & 28 & - & - & 37.9 & 72 (1.9) & 31 & $(0.8)$ & 7 & $(0.2)$ & $8 \quad(0.2)$ & $65 \quad(1.7)$ \\
\hline & Total stand & & & - & 127.9 & $346(2.7)$ & 152 & $(1.2)$ & 22 & $(\mathbf{0 . 2})$ & $19(0.2)$ & $191(1.5)$ \\
\hline \multirow[t]{3}{*}{ Chimay } & Quercus petraea & $37-182$ & 21 & 16.8 & $154.4[9.2]$ & $380(2.5)[22.6]$ & 192 & (1.2) [11.4] & 29 & $(0.2)[1.7]$ & $23(0.1)[1.4]$ & 602 (3.9) [35.8] \\
\hline & Carpinus betulus & $\approx 20-50$ & 13 & 8.0 & 36.9 [4.6] & $118(3.2)[14.8]$ & 36 & (1.0) $[4.5]$ & 10 & $(0.3)$ [1.3] & $11(0.3)[1.4]$ & 88 (2.4) [11.0] \\
\hline & Total stand & & & 24.8 & 191.3 [7.7] & $498(2.6)[20.1]$ & 228 & (1.2) [9.2] & 39 & $(0.2)[1.6]$ & $34(0.2)[1.4]$ & $690(3.6)[27.8]$ \\
\hline \multirow[t]{5}{*}{ Virelles $^{(3)}$} & Quercus robur & 75 & 20 & 8.0 & $41.9[5.2]$ & $122(2.9)[15.3]$ & 63 & (1.5) $[7.9]$ & 11 & $(0.3)[1.4]$ & $38(0.9)[4.8]$ & $300(7.2)[37.5]$ \\
\hline & Fagus sylvatica & 75 & 20 & 4.8 & $29.5[6.1]$ & 65 (2.2) [13.5] & 47 & (1.5) $[9.8]$ & 4.1 & $(0.1)[0.9]$ & $15(0.5)[3.1]$ & 135 (4.6) [28.1] \\
\hline & Carpinus betulus & 35 & 13 & 7.7 & $37.7[4.9]$ & $94 \quad(2.5)[12.2]$ & 49 & (1.3) $[6.4]$ & 6.4 & $(0.2)[0.8]$ & $17(0.5)[2.2]$ & 306 (8.1) [39.7] \\
\hline & Acer campestre & & & 0.7 & 3.0 [4.3] & & & & & & & \\
\hline & Total stand & & & 21.2 & $112.2[5.2]$ & $281(2.6)[13.3]$ & 159 & (1.5) [7.5] & 21.5 & (0.2) [1.0] & $40(0.4)[1.9]$ & $741(6.8)[35.0]$ \\
\hline \multirow{4}{*}{ Wavreille $^{(4)}$} & Quercus robur & 120 & 24 & 26.3 & 298.2 [11.3] & 732 & 375 & (1.3) [14.3] & 47 & $(0.2)[1.8]$ & $91(0.3)[3.5]$ & 1 [ 149 (3.9) [43.7] \\
\hline & Carpinus betulus & 20 & 7 & 9.0 & 29.3 [3.3] & $111(3.8)[12.3]$ & 52 & (1.8) [5.8] & 8 & $(0.3)$ [0.9] & $25(0.9)[2.8]$ & $146(5.0)[16.2]$ \\
\hline & Corylus avellana & & & & & & & & & & & \\
\hline & Total stand & & & 35.3 & $327.5[9.3]$ & $843(2.6)[23.9]$ & 427 & (1.30) [12.1] & 55 & $(0.2)[1.6]$ & $116(0.4)[3.3]$ & $1295(4.0)$ [36.7] \\
\hline \multirow[t]{3}{*}{ Gontrode $^{(5)}$} & Quercus robur & 72 & - & 16.5 & $134.8[8.2]$ & $326(2.4)[19.8]$ & 111 & (0.8) [6.7] & 22 & $(0.2)[1.3]$ & $27(0.2)[1.6]$ & 242 (1.8) [14.6] \\
\hline & Fagus sylvatica & & - & 11.2 & 111.3 [9.9] & $263(2.4)[23.5]$ & 118 & (1.1) [10.5] & 10 & $(0.1)[0.9]$ & $22(0.2)[2.0]$ & 206 (1.9) [18.4] \\
\hline & Total stand & & - & 27.7 & 246.1 [8.9] & $589(2.4)[21.3]$ & 229 & (0.9) $[8.3]$ & 32 & $(0.1)[1.2]$ & $49(0.2)[1.8]$ & 449 (1.8) [16.2] \\
\hline
\end{tabular}

(1) Values between brackets are ratios between nutrient content and corresponding biomass $(\mathrm{kg} / \mathrm{t}$ or $\mathrm{g} / \mathrm{kg})$. Values between square brackets are ratios between nutrient content and basal area $\left(\mathrm{kg} / \mathrm{m}^{2} \mathrm{BA}\right)$ or between biomass and basal area $\left(\mathrm{t} / \mathrm{m}^{2} \mathrm{BA}\right)$.

(2) Nys et al. [21].

(3) Duvigneaud et al. [9], Froment at al. [13].

(4) Duvigneaud et al. [9, 11].

(5) Mussche et al. [20].

\subsubsection{Branch diameter effect}

In agreement with our results, decreasing $\mathrm{N}, \mathrm{P}, \mathrm{K}, \mathrm{Mg}$, $\mathrm{S}$ concentrations from thinner live branches to thicker ones were also reported by Duvigneaud et al. [10] for oak and hornbeam, and by Mussche et al. [20] for oak only. The contrasting evolution of $\mathrm{Ca}$ concentrations between wood and bark tissues as a function of oak branch diameter was also observed by Duvigneaud et al. [10].

\subsection{Biomass and nutrient content}

\subsubsection{Tree level}

Our results can be compared to those obtained by Duvigneaud et al. [10] for a mixed broadleaved forest located in Virelles (Belgium). For trees of comparable circumference, total individual biomass tends to be higher in Chimay than in Virelles, the differences increasing with tree size up to a maximum of $33 \%$. These differences may first be explained by the smaller total height of trees sampled in Virelles. Both stem and crown were responsible for these differences in total individual biomasses, yet to a lesser extent for the crowns. It should, however, be noticed that the criterion used to separate crown from stem differed between studies: in Virelles, use was made of the height at which diameter equals that of the thickest branch $(\mathrm{Htb})$, whereas the separation was based on Delevoy height $(\mathrm{Hd})$ in Chimay. These contrasting stem definitions led to important differences, Hd being higher than Htb by a value exceeding largely total tree height differences. Differences in wood infradensity between the two stands can be rejected as an hypothesis, since mean annual circumference increments of trees were around $1.2 \mathrm{~cm}^{\text {year }}{ }^{-1}$ in both stands. Crown biomass differences probably resulted from differences in crown shape (e.g. branch number, crown lateral development, etc.); this hypothesis could however not be tested due to the lack of any crown measurements in the Virelles study. The ratio of stem to total biomass was about the same for trees of comparable girths; in addition, the distribution of crown biomass between the various branch classes was also similar in the two stands.

\subsubsection{Stand level}

Table VIII summarises the biomass and nutrient content data from a series of stands: one is a coppice-with-standards 
stand located in the French Ardennes [21, 25], the four other ones are located in Belgium ([9, 11, 13, 20], this study). Numbers between brackets are ratios of stand nutrient contents to stand biomass (i.e. global mean concentrations), and those in square brackets are ratios of biomass or nutrient contents to stand basal area; comparisons between stands can thus be made on a same reference unit.

As shown in Table VIII, the ranking of Belgian sites is similar for total stand biomass and basal area, with Wavreille $>$ Gontrode $>$ Chimay $>$ Virelles. Wavreille has by far the highest nutrient contents, whereas the lowest values are found either for Château-Régnault or Virelles, depending on the element. Contrary to bulk nutrient contents at the stand level, global mean concentrations (i.e. the ratio of nutrient content to biomass) are much more comparable between the five stands for a given species, at least for $\mathrm{N}$ (hornbeams, $\mathrm{h}$ : $\min -\mathrm{max}$ ratios of 2.5-3.8 $\mathrm{g} \mathrm{kg}^{-1}$, respectively; oaks, o: 2.4-3.0 $\mathrm{g} \mathrm{kg}^{-1}$ ), $\mathrm{P}$ (h and o: $0.2-0.3 \mathrm{~g} \mathrm{~kg}^{-1}$ ), and $\mathrm{K}$ (h: $1.0-1.8 \mathrm{~g} \mathrm{~kg}^{-1}$; $0: 0.8-$ $\left.1.5 \mathrm{~g} \mathrm{~kg}^{-1}\right)$. This matches the observations of Augusto et al. [2] who, compiling literature data, observed linear relationships between aerial biomass and nutrient content of adult stands for different species. For both hornbeams and oaks, the global mean concentrations were found to be much more variable for $\mathrm{Ca}$; the highest values were associated to the Virelles stand, probably as a result of the corresponding high exchangeable Ca soil pool (not shown).

When using basal area as a reference, values (kg of element $\mathrm{m}^{-2}$ basal area) obtained for oak in Wavreille are systematically over those of the other stands, except for Mg. For hornbeam, the ranking of the three relevant stands depends on the element, with a remarkably high value for $\mathrm{Ca}$ in Virelles.

\subsection{Harvesting implications}

\subsubsection{Comparison between nutrient contents in standing crop and soil pools}

Total aboveground nutrient contents (Tab. VII) can be compared to either exchangeable or total (i.e. Kjeldahl $\mathrm{N}$ or aqua regia digestion for the other elements) soil pools in the 0 $40 \mathrm{~cm}$ mineral layer (Tab. I). For $\mathrm{N}$ and $\mathrm{P}$, nutrient accumulation in tree biomass is much lower than extractable soil amounts. Quite contrasting patterns are observed between base cations, depending on the soil pool. When considering exchangeable elements, the ratio between tree nutrient contents and soil pools ranks according to $0.3,0.8$, and 2.7 for $\mathrm{Mg}$, $\mathrm{K}$, and $\mathrm{Ca}$, respectively; when total soil amounts are considered, the ratio decreases to values less than $10^{-2}$ for both $\mathrm{Mg}$ and $\mathrm{K}$, but remains above unity for $\mathrm{Ca}$. Among the investigated base cations, $\mathrm{Ca}$ is surprisingly associated with both the highest aboveground pools and the lowest total soil reserves, the latter being one order of magnitude below those of $\mathrm{Mg}$ and $\mathrm{K}$. The apparent contradiction between aboveground $\mathrm{Ca}$ accumulation in trees and belowground reserves probably results from a discrepancy between the soil pools in the actual rooting zone, and those of the $0-40 \mathrm{~cm}$ soil depth. Some borings indeed detected live oak roots well below $40 \mathrm{~cm}$ depth.

\subsubsection{Tissue composition}

Tissue separation in oaks showed important concentrations differences between tissues for stems and branches (diameter > $7 \mathrm{~cm}$ ). The concentrations of all elements increased from heartwood to sapwood and bark (stems), or from wood to bark (branches). The relative difference between tissues was however element-dependent. At the stem level for instance, the mean ratios between bark and wood amounted to $3.8(\mathrm{~K}, \mathrm{~S})$, $5.0(\mathrm{~N}), 7.1(\mathrm{P}), 11.1(\mathrm{Mg})$, and $71.1(\mathrm{Ca})$. So, although the contribution of bark to stem biomass was about $8 \%$, its contribution to stem nutrient contents at the stand level varied from $22 \%(\mathrm{~S}), 25 \%(\mathrm{~K}), 29 \%(\mathrm{~N}), 44 \%(\mathrm{P}), 52 \%(\mathrm{Mg})$, and $88 \%$ (Ca). These results point the potential usefulness of oak stem debarking in limiting nutrient exports from the stands.

\subsubsection{Nutrient contents in the crown}

This study gave very detailed information on the contribution of various branch sizes to biomass and nutrient contents in the experimental stand (Tab. VII). Compared to stem harvesting, the additional nutrients exports associated with crown exploitation may differ to considerable extents, depending both on the element and on the branch size class. Two harvesting scenarios are given as examples, assuming the felling of all oak trees from the stand described in Table VII. If harvesting includes all oak branches larger than $>7 \mathrm{~cm}$ diameter, the additional nutrient exports would range from $55.5 \%$ of oak stem nutrient contents for $\mathrm{Ca}$ to $129 \%$ for $\mathrm{Mg}$; when total crown harvesting is considered, the corresponding additional outputs would vary from $85 \%(\mathrm{Ca})$ to $281 \%(\mathrm{Mg})$. These examples clearly demonstrate the importance of assessing the specific pattern of nutrient distribution between the various tree components when giving recommendations for harvesting. This is of special concern in the present context of energy sources diversification, where a more complete tree utilisation is considered.

Acknowledgements: This research was initiated by the Regional Forest Service (Division de la Nature et des Forêts, DNF) and funded by the Regional Ministry of Agriculture (contract 99-43.723). We are grateful to Ir. A. Barjasse and the local foresters for giving us access to the plot. We wish to thank P. Giot, A. Vercruysse and the local authority of Chimay for technical and material assistance. Sampling on the ground and pretreatments of samples were carried out by $\mathrm{F}$. Hardy, F. Plume, O. Bouchez, S. Taziaux, A. Horten, M. Mariage and O. Risselin. Many thanks to K. Henin, V. van Hese and L. Gerlache for processing the chemical analyses. We also thank the two anonymous reviewers for their helpful comments and remarks on an earlier version of the manuscript.

\section{REFERENCES}

[1] Attiwill P.M., Guthrie H.B., Leuning R., Nutrient cycling in a Eucalyptus obliqua (L'Hérit.) Forest. I. Litter production and nutrient return, Aust. J. Bot. 26 (1978) 79-91.

[2] Augusto L., Ranger J., Ponette Q., Rapp M., Relationships between forest tree species, stand production and stand nutrient amount, Ann. For. Sci. 57 (2000) 313-324.

[3] Bamber R.K., Fukazawa K., Sapwood and heartwood: a review, Forestry Abstracts 46 (1985) 567-580. 
[4] Bardsley C.E., Lancaster J.D., Determination of Reserve Sulfur and Soluble Sulfates in Soils, Proc. Soil Sci. Soc. Am. 24 (1960) 265 268.

[5] Bouchon J., Nys C., Ranger J., Cubage, biomasse et minéralomasse: comparaison de trois taillis simples des Ardennes primaires, Acta Oecol. 6 (1985) 53-72.

[6] Caldeira M.V.W., Schumacher M.V., Spathelf P., Quantification of nutrient content in above-ground biomass of young Acacia mearnsii De Wild., provenance Bodalla, Ann. For. Sci. 59 (2002) 833-838.

[7] Colin-Belgrand M., Ranger J., d'Argouges S., Transferts internes d'éléments nutritifs dans le bois de châtaignier (Castanea sativa Miller) : approche dynamique sur une chronoséquence de peuplements. I. Distribution des éléments minéraux, Acta Oecol. 14 (1993) $653-680$.

[8] De Visser P.H.B., The relations between chemical composition of oak tree rings, leaf, bark, and soil solution in a partly mixed stand, Can. J. For. Res. 22 (1992) 1824-1831.

[9] Duvigneaud P., Denayer-De Smet S., Cycle des éléments biogènes dans les écosystèmes forestiers d'Europe (principalement forêts caducifoliées), in: Duvigneaud P. (Ed.), Productivity of forest ecosystems, Unesco, Paris, 1971, pp. 527-542.

[10] Duvigneaud P., Denayer S., Ambroes P., Timperman J., Recherches sur l'écosystème forêt : biomasse, productivité et cycle des polyéléments biogènes dans l'écosystème "chênaie caducifoliée". Essai de phytogéochimie forestière, Institut Royal des Sciences Naturelles de Belgique, Bruxelles, 1971.

[11] Duvigneaud P., Kestemont P., Ambroes P., Productivité primaire des forêts tempérées d'essences feuillues caducifoliées en Europe occidentale, in: Duvigneaud P. (Ed.), Productivity of forest ecosystems, Unesco, Paris, 1971, pp. 259-270.

[12] Foyer C., Spencer C., The relationship between phosphate status and photosynthesis in leaves, Planta 167 (1986) 369-375.

[13] Froment A., Tanghe M., Duvigneaud P., Galoux A., Denayer-De Smet S., Schnock G., Grulois J., Mommaerts-Billiet F., Vanséveren J.P., La chênaie mélangée calcicole de Virelles-Blaimont, en haute Belgique, in: Duvigneaud P. (Ed.), Productivity of forest ecosystems, Unesco, Paris, 1971, pp. 635-666.

[14] Jose S., Gillespie A., Aboveground production efficiency and canopy nutrient contents of mixed hardwood forest communities along a moisture gradient in the central United States, Can. J. For. Res. 26 (1996) 2214-2223.

[15] Kowalik P.J., Bio-energy in eastern Europe (taking Poland as an example), J. Sustain. Forest. 1 (1993) 9-21.
[16] Lecomte H., Florkin P., Thirion M., L'inventaire des massifs forestiers de la Walonie : aperçu global de la situation en 1996, Ministère de la Région Wallonne, Namur, 1997.

[17] Lévy G., Bréchet C., Becker M., Element analysis of tree rings in pedunculate oak heartwood: an indicator of historical trends in the soil chemistry, related to atmospheric deposition, Ann. Sci. For. 53 (1996) 685-696.

[18] Littell R.C., Milliken G.A., Stroup W.W., Wolfinger R.D., SAS ${ }^{\circledR}$ System for Mixed Models, SAS Institute Inc., Cary, 1996.

[19] Millier C., Nys C., Ranger J., L'échantillonnage dans l'étude de la minéralomasse forestière : l'exemple des taillis ardennais, Ann. Sci. For. 43 (1986) 165-178.

[20] Mussche S., Bussche B., De Shrijver A., Neirynck J., Nachtergale L., Lust N., Nutrient uptake of a mixed oak/beech forest in Flanders (Belgium), Silva Gandavensis 63 (1998) 120-133.

[21] Nys C., Ranger D., Ranger J., Étude comparative de deux écosystèmes forestiers feuillus et résineux des Ardennes primaires françaises. III. Minéralomasse et cycle biologique, Ann. Sci. For. 40 (1983) 41-68.

[22] Olsson B.A., Bengtsson J., Lundkvist H., Effects of different forest harvest intensities on the pools of exchangeable cations in coniferous forest soils, For. Ecol. Manage. 84 (1996) 135-147.

[23] Penninckx V., Glineur S., Gruber W., Herbauts J., Meerts P., Radial variations in wood mineral element concentrations: a comparison of beech and pedunculate oak from the Belgian Ardennes, Ann. For. Sci. 58 (2001) 253-260.

[24] Ranger J., Bonneau M., Effets prévisibles de l'intensification de la production et des récoltes sur la fertilité des sols de forêt. Le cycle biologique en forêt, Ann. Sci. For. 36 (1984) 93-112.

[25] Ranger J., Nys C., Ranger D., Étude comparative de deux écosystèmes forestiers feuillus et résineux des Ardennes primaires françaises. I. Biomasse aérienne du taillis-sous-futaie, Ann. Sci. For. 38 (1981) 259-282.

[26] Remy J., Carte des sols de la Belgique : texte explicatif de la planchette de Rance 181 E, I.R.S.I.A., Bruxelles, 1990.

[27] Rochon P., Paré D., Messier C., Development of an improved model estimating the nutrient content of the bole for four boreal tree species, Can. J. For. Res. 28 (1998) 37-43.

[28] Thierron V., Laudelout H., Contribution of root respiration to total $\mathrm{CO} 2$ efflux from the soil of a deciduous forest, Can. J. For. Res. 26 (1996) 1142-1148.

[29] Ung C.H. Végiard S., Problèmes d'inférence statistique reliés à la transformation logarithmique en régression, Can. J. For. Res. 18 (1988) 733-738. 